\title{
Analysis Of The Effect Of Frequency Decrease On Performance On Five Phase Induction Motor
}

\author{
Suranta Sitorus \\ Department Of Electrical Engineering, University Of North Sumatra, Jl. Dr. Mansur No. 9 Padang Bulan, Kec. \\ Medan Baru, Kota Medan 20222
}

\begin{tabular}{|c|c|}
\hline ARTICLE INFO & ABSTRACT \\
\hline Article history: & \multirow{3}{*}{$\begin{array}{l}\text { Almost } 70 \% \text { of the energy produced by the generator is consumed } \\
\text { by electric motors. The use of induction motors in industry and } \\
\text { factories is more profitable than DC or synchronous motors, one of } \\
\text { the advantages is easy maintenance and high efficiency. On } \\
\text { machines in the industry speed regulation is absolutely necessary. } \\
\text { Along with the development of power electronics, this has become } \\
\text { very easy to do, namely by supplying a motor with a variable speed } \\
\text { drive (VSD) inverter. With the supply of a variable speed drive } \\
\text { inverter, it is possible to adjust the motor speed by adjusting the } \\
\text { voltage frequency. This study was conducted to determine the effect } \\
\text { of decreasing the frequency using a variable speed drive inverter on } \\
\text { the performance of a five-phase induction motor. Tests are carried } \\
\text { out at a frequency of } 50 \mathrm{~Hz} \text { (grid frequency), 35, 40, } 45,50 \mathrm{~Hz} \\
\text { (inverter frequency) and the motor is loaded at } 0.5,1,1.5,2,2.5 \mathrm{Nm} \text {. } \\
\text { From the research, it was concluded that, among others, the use of } \\
\text { a variable speed drive inverter resulted in greater motor losses and } \\
\text { the motor produced a louder sound. At the same frequency ( } 50 \mathrm{~Hz} \text { ) } \\
\text { the efficiency of the motor is better when supplied directly from the } \\
\text { grid. }\end{array}$} \\
\hline $\begin{array}{r}\text { Received Aug 04, } 2021 \\
\text { Revised Sep 08, } 2021 \\
\text { Accepted Oct 30, } 2021\end{array}$ & \\
\hline $\begin{array}{r}\text { Keywords: } \\
\text { Induction Motor } \\
\text { Inverter } \\
\text { Inverter Variable Speed Drive }\end{array}$ & \\
\hline
\end{tabular}

This is an open access article under the CC BY-NC license.

\section{Corresponding Author:}

Suranta Sitorus,

Department Electrical Engineering,

University Of North Sumatra,

Jl. Dr. Mansur No. 9 Padang Bulan, Kec. Medan Baru, Kota Medan 20222.

Email : surantasitorus@gmail.com

\section{INTRODUCTION}

Induction motors are alternating current motors that are most often used in industry and households. This is because the induction motor is very easy to operate. In addition, the construction of the induction motor has a strong construction, and has good efficiency and constant rotation for every change in load.

In everyday life we find many kinds of motorcycles. In this case, the development of a threephase induction motor into a five-phase induction motor is carried out. In theory and calculations, the five-phase motor is more efficient and the power generated is greater than the three-phase induction motor.

The problem of decreasing the frequency of a five-phase induction motor is one of the problems in the operation of a five-phase induction motor. The decrease in frequency in the operation of a five-phase induction motor will result in changes in the performance of the induction 
motor. This is because the decrease in frequency will cause a decrease in the speed of the rotating field on the stator, which will then affect the working efficiency of the five-phase induction motor.

Therefore, it is necessary to conduct a study in the form of analysis and research in the laboratory to see how the effect of decreasing the frequency on the performance of a five-phase induction motor, as well as comparing the performance of a five-phase induction motor at each value of the decrease in frequency.

\section{RESEARCH METHOD}

\subsection{Place and time}

The research was carried out at the Central Laboratory for the Development and Empowerment of Educators and Education Personnel (P4TK) Medan in the Building and Electrical Sector, Department of Electrical Engineering. The research was carried out after the completion of the seminar the proposal was approved. The length of the research was carried out for 3 (three) days, starting from 14 to 16 November 2016.

\subsection{Research Implementation}

In carrying out the research, the required data are taken first. The required data is then analyzed and calculated according to the relevant formula. Then the results obtained are presented in the form of tables and curves.

\subsection{Observed Variables}

The variables observed in this study include:

a. Frequency

b. Load Torque

c. Voltage

d. Current

e. Power Factor

f. Motor Speed

\section{RESULTS AND DISCUSSIONS}

To be able to see the effect of decreasing the frequency on the performance of a five-phase induction motor, it is necessary to experiment with loading an induction motor that works in a normal frequency state and also in a reduced frequency state, so that a comparison can be obtained that can state the difference between each of these conditions.

In this experiment, the effect of decreasing the frequency will be seen in a five-phase induction motor with a cage rotor.

\subsection{Zero Load Trial}

a. Experiment Series

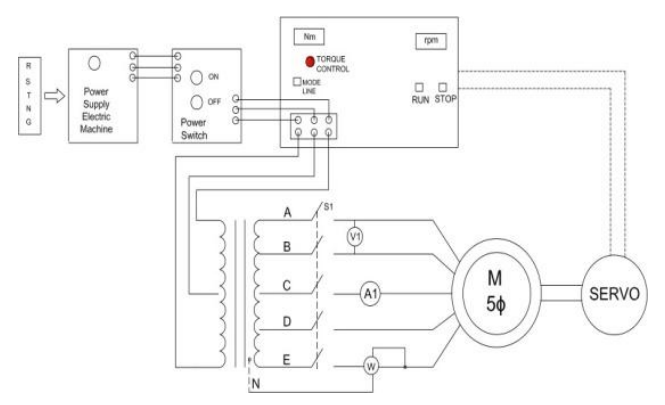

Figure 1. Five Phase Induction Motor Zero Load Experiment Circuit 


\section{b. Trial Procedure}

a. Arrange the experiment as shown in Figure 4.1

b. Close switch S1.

c. Increase the AC autotransformer (PTAC) voltage to be supplied by the induction motor until it reaches 380 volts.

d. Set the load torque value to $0 \mathrm{Nm}$

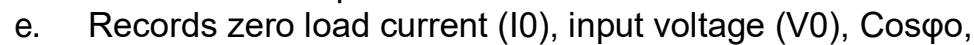
motor speed (rpm) and input power (Pin).

f. Lower the AC autotransformer (PTAC) until the motor stops.

g. Release switch S1

h. Experiment complete

\section{c. Experimental Data}

Table 1. Zero Load Test Result Data

\begin{tabular}{cccc}
\hline V0 (Volts) & 10 (Amperage) & Coso & $\mathrm{nr}(\mathrm{rpm})$ \\
\hline 250 & 3.75 & 0.63 & 1452 \\
\hline
\end{tabular}

Table 2. Results of Zero Load Test Experiment Data Analysis

\begin{tabular}{ccccc}
\hline Vo (Volts) & lo (Amperage) & Pins (Watts) & $\mathrm{RM}(\Omega)$ & $\mathrm{Xm}(\Omega)$ \\
\hline 250 & 3.75 & 2510,16 & 104.16 & 86.21
\end{tabular}

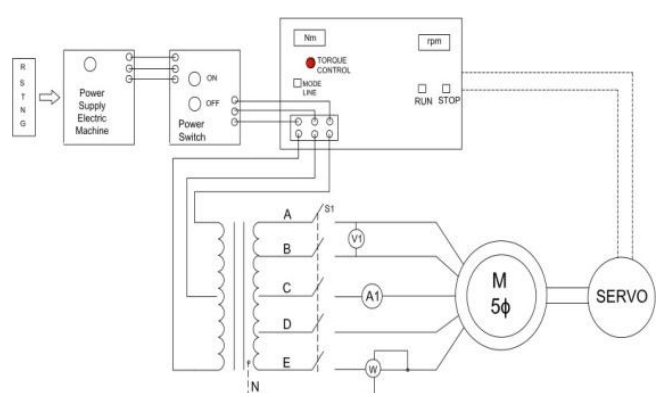

Figure 2. Experimental circuit of 5 phase induction motor is supplied from the grid

\section{d. Trial Procedure}

1) Arrange the experiment as shown in the picture

2) Close switch S1.

3) Increase the AC autotransformer (PTAC) voltage that will be supplied to the induction motor until it reaches 380 volts.

4) Set the load torque value to $0.5 \mathrm{Nm}$

5) Records current (I), input voltage (V), Coso, and motor speed (rpm). The 4th step is carried out for load torques of $1 \mathrm{Nm}, 1.5 \mathrm{Nm}$, $2 \mathrm{Nm}$ and $2.5 \mathrm{Nm}$

6) Lower the AC autotransformer (PTAC) until the motor stops.

7) Release switch S1.

8) Experiment finished. 


\section{e. Experimental Data}

Table 3. Experimental Data of a 5-phase Induction Motor supplied from the grid

\begin{tabular}{ccccc}
\hline Tload $(\mathrm{Nm})$ & V (volts) & I (amperes) & Cos & $\mathrm{nr}(\mathrm{rpm})$ \\
\hline 0.5 & 250 & 4 & 0.66 & 1438 \\
1 & 250 & 4.1 & 0.68 & 1426 \\
1.5 & 250 & 4.2 & 0.68 & 1414 \\
2 & 250 & 4.3 & 0.7 & 1397 \\
2.5 & 250 & 4.5 & 0.72 & 1374 \\
\hline
\end{tabular}

\subsection{Data Analysis of Experimental Results}

In this chapter, the losses and efficiency of the induction motor are calculated when the motor is supplied from the grid. This data analysis aims to obtain the value of the comparison of losses and the efficiency of the motor when it is supplied from the grid and supplied from the inverter variable speed drive. For this reason, the author takes the example of the calculation at a load of $0.5 \mathrm{Nm}$ at a grid frequency of $50 \mathrm{~Hz}$.

Table 4. Results of Analysis of a 5-phase Induction Motor supplied from the grid

\begin{tabular}{ccccccccc}
\hline Tload $(\mathrm{Nm})$ & $\begin{array}{c}\mathrm{V} \\
\text { (volt) }\end{array}$ & $\begin{array}{c}\mathrm{I} \\
\text { (amperes) }\end{array}$ & Cos & $\begin{array}{c}\mathrm{nr} \\
\text { (rpm) }\end{array}$ & Slip & $\begin{array}{c}\text { Pin } \\
\text { (watt) }\end{array}$ & $\begin{array}{c}\text { Pouts } \\
\text { (watts) }\end{array}$ & $\begin{array}{c}\text { (\%) } \\
0\end{array}$ \\
250 & 3.75 & 0.63 & 1452 & 0.032 & 2510.16 & - & - \\
0.5 & 250 & 4 & 0.66 & 1438 & 0.0413 & 2805 & 102.83 & 3.6 \\
1 & 250 & 4.1 & 0.68 & 1426 & 0.0493 & 2962.25 & 196.565 & 6.6 \\
1.5 & 250 & 4.2 & 0.68 & 1414 & 0.0573 & 3034.5 & 208.96 & 6.8 \\
2 & 250 & 4.3 & 0.70 & 1397 & 0.0686 & 3198,125 & 302.12 & 9.45 \\
2.5 & 250 & 4.5 & 0.72 & 1374 & 0.084 & 3442.5 & 407,644 & 11.84 \\
\hline
\end{tabular}

\subsection{Experimental 5 Phase Induction Motor Supplied From Inverte Variable Speed Drive (VSD)}

\section{a. Experiment Series}

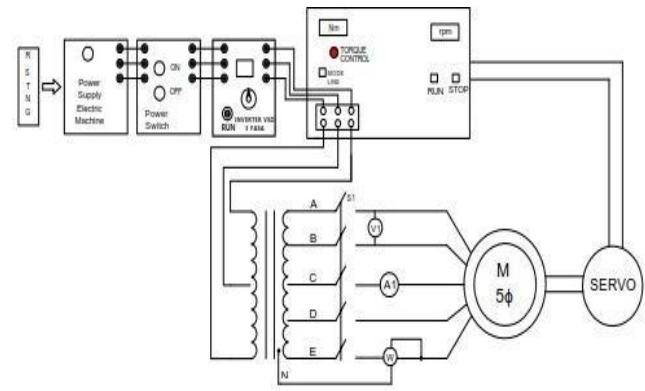

Figure 3. The 5 phase induction motor experiment circuit is supplied from a variable speed drive inverter

\section{b. Trial Procedure}

1) Arrange the experiment as shown in the picture

2) Close switch $S 1$.

3) Increase the AC autotransformer (PTAC) voltage that will be supplied to the induction motor until it reaches 380 volts.

4) Set the load torque value to $0.5 \mathrm{Nm}$

5) The inverter variable speed drive output frequency is set by turning the selector on the inverter variable speed drive. In this experiment the selected frequencies are $35,40,45$, $50 \mathrm{~Hz}$. 
6) The frequency of the inverter variable speed drive is set at a frequency of $35 \mathrm{~Hz}$, pressing the RUN button on the inverter variable speed drive to run the motor. The stopwatch is turned on to determine the operating time of the motor.

7) Records current (I), input voltage (V), Coso, and motor speed (rpm). The 4th step is carried out for a load torque of $1 \mathrm{Nm}$ and $1.5 \mathrm{Nm}$. Lower the AC autotransformer (PTAC) until the motor stops.

8) Release switch S1.

9) The experiment was carried out again for the frequency value of the 40,45 and $50 \mathrm{~Hz}$ variable speed drive inverter.

\section{c. Experimental Data}

Table 5. The data from the induction motor test is supplied from the Inverter Variable Speed Drive (VSD) for a frequency of $35 \mathrm{~Hz}$

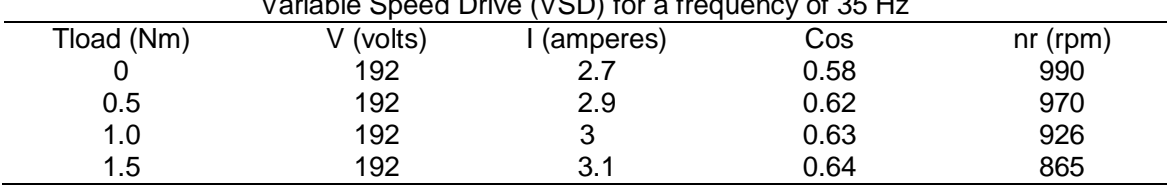

Table 6. The data from the induction motor test is supplied from the Inverter Variable Speed Drive (VSD) for a frequency of $40 \mathrm{~Hz}$

\begin{tabular}{ccccc}
\hline Tload $(\mathrm{Nm})$ & V (volts) & I (amperes) & Cos & $\mathrm{nr}(\mathrm{rpm})$ \\
\hline 0 & 200 & 2.75 & 0.6 & 1106 \\
0.5 & 200 & 3 & 0.63 & 1076 \\
1.0 & 200 & 3.1 & 0.64 & 1021 \\
1.5 & 200 & 3.2 & 0.65 & 994 \\
\hline
\end{tabular}

Table 7. The data from the induction motor test is supplied from the Inverter Variable Speed Drive (VSD) for a frequency of $45 \mathrm{~Hz}$

\begin{tabular}{ccccc}
\hline Tload $(\mathrm{Nm})$ & V (volts) & I (amperes) & Cos & $\mathrm{nr}(\mathrm{rpm})$ \\
\hline 0 & 209 & 2.8 & 0.61 & 1245 \\
0.5 & 209 & 3.1 & 0.64 & 1224 \\
1.0 & 209 & 3.2 & 0.65 & 1186 \\
1.5 & 209 & 3.3 & 0.66 & 1135 \\
\hline
\end{tabular}

Table 8. The data from the induction motor test is supplied from the Inverter Variable Speed Drive (VSD) for a frequency of $50 \mathrm{~Hz}$

\begin{tabular}{ccccc}
\hline Tload $(\mathrm{Nm})$ & V (volts) & I (amperes) & Cos & $\mathrm{nr}(\mathrm{rpm})$ \\
\hline 0 & 220 & 2.95 & 0.62 & 1395 \\
0.5 & 220 & 3.2 & 0.65 & 1378 \\
1.0 & 220 & 3.25 & 0.66 & 1326 \\
1.5 & 220 & 3.4 & 0.67 & 1210 \\
\hline
\end{tabular}

\section{d. Experimental Data Analysis}

Table 9. Data analysis results of 5 phase induction motor are supplied from inverter variable speed

\begin{tabular}{ccccccccc}
\multicolumn{10}{c}{ drive (frequency 35 Hz) } \\
\hline Tload (Nm) & $\begin{array}{c}\mathrm{V} \\
\text { (volt) }\end{array}$ & $\begin{array}{c}\text { I } \\
\text { (amperes) }\end{array}$ & Cos & Nr (rpm) & Slip & Pin (watt) & $\begin{array}{l}\text { Pouts } \\
\text { (watts) }\end{array}$ & $(\%)$ \\
\hline 0 & 174 & 2.7 & 0.58 & 990 & 0.34 & 1158,05 & - & - \\
0.5 & 174 & 2.9 & 0.62 & 970 & 0.353 & 1329.62 & 36.14 & 2.71 \\
1 & 174 & 3 & 0.63 & 926 & 0.382 & 1397.65 & 49.72 & 3.55 \\
1.5 & 174 & 3.1 & 0.64 & 865 & 0.423 & 1467,16 & 59.84 & 4.0 \\
\hline
\end{tabular}


Table 10. The data from the analysis of the 5 phase induction motor is supplied from the inverter variable speed drive (frequency $40 \mathrm{~Hz}$ )

\begin{tabular}{|c|c|c|c|c|c|c|c|c|}
\hline $\begin{array}{l}\text { Tload } \\
(\mathrm{Nm})\end{array}$ & $\begin{array}{c}\mathrm{V} \\
\text { (volt) }\end{array}$ & $\begin{array}{c} \\
\text { (amperes) }\end{array}$ & Cos & $\begin{array}{c}\mathrm{nr} \\
(\mathrm{rpm})\end{array}$ & Slip & $\begin{array}{r}P_{\text {in }} \\
\text { (watt) }\end{array}$ & $\begin{array}{l}\text { Pouts } \\
\text { (watts) }\end{array}$ & (\%) \\
\hline 0 & 200 & 2.75 & 0.6 & 1106 & 0.262 & 1402.5 & - & - \\
\hline 0.5 & 200 & 3 & 0.63 & 1076 & 0.282 & 1606.5 & 45.59 & 2.83 \\
\hline 1 & 200 & 3.1 & 0.64 & 1021 & 0.319 & 1686.4 & 66.73 & 3.95 \\
\hline 1.5 & 200 & 3.2 & 0.65 & 994 & 0.337 & 1768 & 88,72 & 5.01 \\
\hline
\end{tabular}

Table 11. Data analysis results of 5 phase induction motor are supplied from inverter variable speed drive (frequency $45 \mathrm{~Hz}$ )

\begin{tabular}{ccccccccc}
\hline $\begin{array}{c}\text { Tload } \\
(\mathrm{Nm})\end{array}$ & $\mathrm{V}$ & I (amperes) & Cos & $\begin{array}{c}\mathrm{Nr} \\
\text { (rpm) }\end{array}$ & Slip & $\begin{array}{c}\text { Pin } \\
\text { (watt) }\end{array}$ & $\begin{array}{c}\text { Pouts } \\
\text { (watts) }\end{array}$ \\
\hline 0 & 209 & 2.8 & 0.61 & 1245 & 0.17 & 1517.13 & - & - \\
0.5 & 209 & 3.1 & 0.64 & 1224 & 0.184 & 1762.28 & 68.59 & 3.8 \\
& & & & & & & & 9 \\
1 & 209 & 3.2 & 0.65 & 1186 & 0.209 & 1847.56 & 97.97 & 5.3 \\
1.5 & 209 & 3.3 & 0.66 & 1135 & 0.243 & 1934.6 & 123.54 & 6.3 \\
& & & & & & & & \\
\hline
\end{tabular}

Table 12. Data from the analysis of the 5 phase induction motor is supplied from the inverter variable speed drive (frequency $50 \mathrm{~Hz}$ )

\begin{tabular}{ccccccccc}
\hline $\begin{array}{c}\text { Tload } \\
(\mathrm{Nm})\end{array}$ & $\begin{array}{c}\mathrm{V} \\
\text { (volt) }\end{array}$ & $\begin{array}{c}\text { I } \\
\text { (amperes) }\end{array}$ & Cos & $\begin{array}{c}\mathrm{nr} \\
\text { (rpm) }\end{array}$ & Slip & $\begin{array}{c}\text { Pin } \\
\text { (watt) }\end{array}$ & $\begin{array}{c}\text { Pouts } \\
\text { (watts) }\end{array}$ & $(\%)$ \\
\hline 0 & 220 & 2.95 & 0.62 & 1395 & 0.07 & 1710.11 & - & - \\
0.5 & 220 & 3.2 & 0.65 & 1378 & 0.081 & 1944,8 & 82.67 & 4.25 \\
1 & 220 & 3.25 & 0.66 & 1326 & 0.116 & 2005,57 & 111.55 & 5.56 \\
1.5 & 220 & 3.4 & 0.67 & 1210 & 0.193 & 2129.93 & 142.6 & 6.69 \\
\hline
\end{tabular}

\section{CONCLUSION}

The reduction in frequency that can be borne by a five-phase induction motor under load conditions is up to a frequency of $35 \mathrm{~Hz}$. This can be seen from the magnitude of the motor speed and the lowest efficiency.

A decrease in the frequency of a five-phase induction motor using an inverter variable speed drive on an induction motor will affect the performance of the induction motor. The current will increase as the frequency decreases, while the voltage, power factor, and motor speed will decrease as the frequency decreases. In addition, the use of a variable speed drive inverter itself affects the amount of load that can be borne by the induction motor. When the motor is supplied from the grid, the load that can be borne by the motor is up to $2.5 \mathrm{Nm}$, while when the motor is supplied from the inverter variable speed drive, the load that can be borne is only up to $1.5 \mathrm{Nm}$. At a load of $1.5 \mathrm{Nm}$, the motor output power when supplied from the grid with a frequency of $50 \mathrm{~Hz}$ is 208.96 watts and when supplied with a variable speed drive inverter with a frequency of $50 \mathrm{~Hz}$ the motor output power is 142, 6 watts. Changes in frequency will affect the efficiency of the induction motor. From the calculation results, at a load of $1.5 \mathrm{Nm}$, the efficiency of the motor when supplied from the grid (frequency $50 \mathrm{~Hz}$ ) is $6.8 \%$ and when the motor is supplied with a variable speed drive inverter (frequency $35,40,45,50 \mathrm{~Hz}$ ) the motor efficiency is successively - respectively $4.07 \%$, $5.01 \%, 6.38 \%$, and $6.69 \%$.

\section{REFERENCES}

Zuhal, "Dasar Teknik Tenaga Listrik dan Elektronika Daya", Penerbit ITB, Bandung, 1988.

Daut, I., "Parameters Calculation of 5 HP AC Induction Motor", Malaysia, 2009. 
NEMA Standard Publications No. MGI-1993. Motors and Generators, Published by National Electrical Manufactures Ascociation. Washington (1993), Part 21 PP. 9-10 and Part 30 PP. 1-2

Rao, K.P. Prasad, "Five-Leg Inverter for Five-Phase Supply", India, 2012.

IEEE Guides: Test Procedures for Synchronus Machines, IEEE Std 115-1995 (R2002).

Theraja, B.L. \& Theraja, A.K., "A Text Book of Electrical Technology", New Delhi, S.Chand and Company Ltd., 2001.

Chapman Stephen J, "Electric Machinery Fundamentals",Third Edition Mc Graw Hill Companies, New York, 1999.

Wijaya Mochtar,"Dasar-dasar Mesin Listrik", Penerbit Djambatan, Jakarta , 2001.

Khan, Rizwan M, "Multi-Phase Alternative Current Machine Winding Design", International Journal of Engineering, Science and Technology, India, 2010.

N, Monika, "Modeling and Simlation of Three-Phase to Five-Phase Transformation Using A Special Transformer Connection”, India, 2013. 